\title{
A new serotype of calicivirus associated with an outbreak of gastroenteritis in a residential home for the elderly
}

\author{
WD CUBITT,* PJ PEAD, AA SAEED
}

From the *Public Health Laboratory and Department of Microbiology, Central Middlesex Hospital, Park Royal, London NW10 7NS, and the Public Health Laboratory, St Mary's Hospital, Milton Road, Portsmouth PO3 6AQ

SUMMARY An outbreak of gastroenteritis involving residents and members of staff in a nursing home for the elderly is described. The agent associated with this episode was a calicivirus which is serologically distinct from two strains causing gastroenteritis in children. We believe that this is the first report of calicivirus infection in adults.

In 1976 Madeley and Cosgrove ${ }^{1}$ reported finding "apparently typical calicivirus particles" in the stools of ten children during a survey of nonbacterial gastroenteritis in Glasgow, but they were unable to attach any significance to the presence of these viruses. Recent reports from the United Kingdom $^{2} 3$ and from Japan ${ }^{4}$ have provided evidence that morphologically similar viruses can cause outbreaks of vomiting and diarrhoea in infants and children. Although adults were at risk in at least two of these outbreaks ${ }^{2} 3$ there was no evidence that they were affected.

This report describes an outbreak of gastroenteritis in a confined community in which 18 elderly residents and 23 members of the staff were affected. Evidence is presented which indicates that the calicivirus associated with this episode is serologically distinct from two strains previously obtained from children. As far as we are aware, this is the first time that a calicivirus has been associated with disease in adults.

\section{CLINICAL FEATURES}

The outbreak occurred during a three week period in January and February 1980. The nursing home housed 18 residents between the ages of 77 and $102 \mathrm{yr}$. There were 32 members of staff, aged between 16 and $68 \mathrm{yr}$ old, who cared for them. The index case is believed to have been a nine-year-old boy who had diarrhoea, headache and repeated bouts of vomiting. His father and the mother who cooked meals for the home, also developed symptoms. During the subsequent three weeks all the elderly residents and a further 22 of the staff became ill. The distribution of symptoms in residents and staff is shown in Table 1.

Table 1 Clinical features in 18 elderly residents and 32 members of staff

\begin{tabular}{lll}
\hline & $\begin{array}{l}\text { Residents } \\
\text { (aged 77-102 yr) }\end{array}$ & $\begin{array}{l}\text { Staff } \\
\text { (aged 16-68 yr) }\end{array}$ \\
\hline Diarrhoea & 18 & 23 \\
Vomiting & 7 & 18 \\
Headache & - & 4 \\
Malaise and aches & - & 3 \\
No symptoms & - & 9 \\
\hline
\end{tabular}

The commonest clinical feature was diarrhoea which occurred in all the 41 cases: 18 staff and seven patients vomited; four staff had headache and three members of the staff complained of malaise and generalised aches and pains. The duration of the illness was between 12 and 36 hours.

Stool specimens were obtained from affected residents and staff. When routine bacteriological investigations failed to reveal Salmonella, Shigella or Campylobacter spp, a few specimens were referred for viral examination. These faecal samples were semi-formed and brown.

\section{Material and methods}

Specimens of stools which had been collected within 24 to 72 hours of the onset of symptoms were received from six of the elderly residents. Acute and convalescent phase sera were obtained from five of 
these individuals, but the sixth resident died before a convalescent phase serum could be collected. The methods used for the preparation and examination of stools and for antibody tests were similar to those previously described. ${ }^{2}$

CROSS REACTIVITY TESTS WITH THREE STRAINS OF "HUMAN CALICIVIRUS"

Acute and convalescent phase sera from the elderly residents were tested against the homologous Portsmouth strain obtained from case 2; Shenley strain from a child involved in a previous outbreak ${ }^{3}$ and Piper strain from a child admitted to hospital with projectile vomiting.

The method for immune electronmicroscopy has been described previously. ${ }^{2}$ The samples of antigen used in these tests were selected because they contained large numbers of free particles of calicivirus. This was a necessary precaution since many stool viruses naturally occur in aggregates.

The acute and convalescent phase sera were titrated in parallel from $1 / 20$ to $1 / 640$ in a series of doubling dilutions. A virus control consisting of $25 \mu \mathrm{l}$ of antigen suspension and $25 \mu \mathrm{l}$ of phosphatebuffered saline was included with each serum.

Evidence of an immune reaction was recorded when aggregates of virus particles clearly linked with antibodies were detected (Fig. 1). A negative result was recorded only if large numbers of single, free particles without antibody were observed.

\section{Results}

The results of the laboratory investigations are summarised in Table 2. Calicivirus particles were detected by EM in $5 / 6$ stools from elderly residents. The size and appearance of these particles (Fig. 2) were indistinguishable from caliciviruses found in outbreaks of gastroenteritis affecting children. ${ }^{23}$ Although all these specimens were collected within 72 hours of the onset of symptoms only one resident, case 2, was excreting sufficient numbers of virus particles for them to be detected by direct examination. However, after differential centrifugation

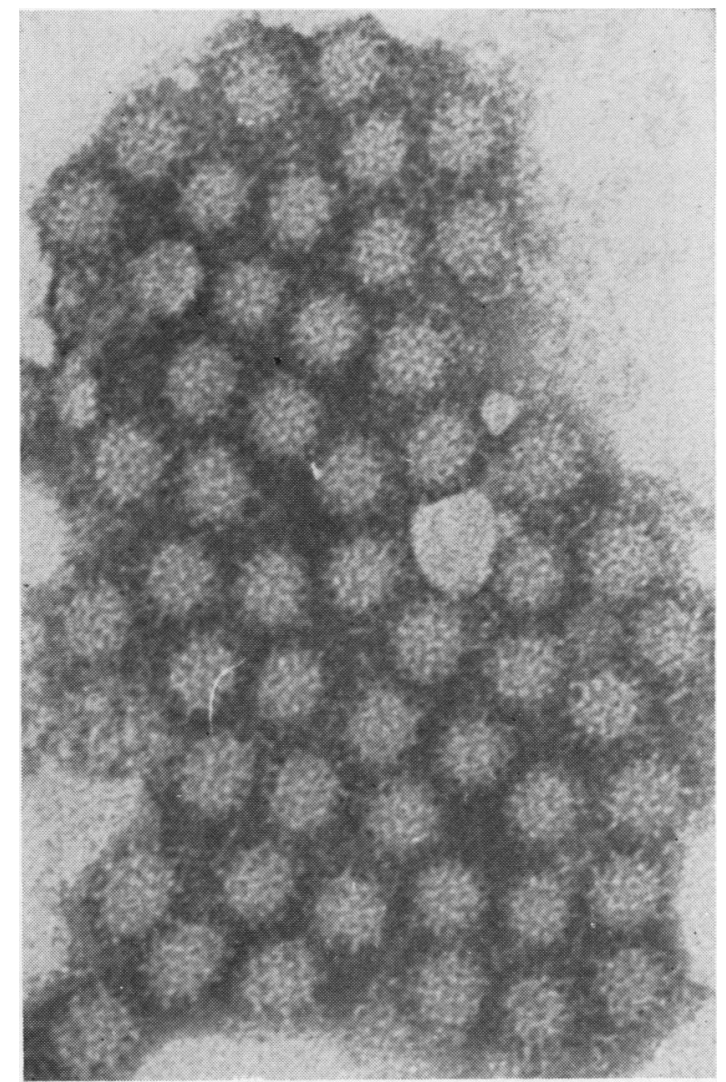

Fig. 1 Immune electronmicroscopy: Caliciviruses linked by antibody $\times 260000$.

virus particles were found in a further four samples. No evidence of virus replication was found in Monkey Kidney or MRC5 cell cultures.

All five residents from whom paired sera were available had significant rises in specific antibody titres to the homologous strain; antibody levels ranged from less than $1 / 20$ in acute phase sera to $1 / 320$ in the convalescent phase samples (Table 2). Calicivirus particles were detected in the stool from

Table 2 Laboratory data on six patients

\begin{tabular}{|c|c|c|c|c|c|c|c|c|}
\hline \multirow[t]{3}{*}{ Case } & \multirow[t]{3}{*}{ Age $(y r)$} & \multirow{3}{*}{$\begin{array}{l}\text { Virus particles detected by } \\
\text { EM }\end{array}$} & \multicolumn{6}{|c|}{ Cross reactivity tests } \\
\hline & & & \multicolumn{2}{|c|}{ Portsmouth } & \multicolumn{2}{|c|}{ Shenley } & \multicolumn{2}{|l|}{ Piper } \\
\hline & & & Acute & Convalescent & Acute & Convalescent & Acute & Convalescent \\
\hline $\begin{array}{l}1 \\
2 \\
3 \\
4 \\
5 \\
6\end{array}$ & $\begin{array}{l}90 \\
93 \\
87 \\
83 \\
72 \\
79\end{array}$ & $\begin{array}{l}+ \\
++ \\
+ \\
+ \\
+ \\
+\end{array}$ & $\begin{array}{r}<20 \\
<20 \\
20 \\
20 \\
<20 \\
20\end{array}$ & $\begin{array}{l}320 \\
320 \\
160 \\
160 \\
320 \\
\text { NA }\end{array}$ & $\begin{array}{r}<20 \\
<20 \\
40 \\
<20 \\
40 \\
20\end{array}$ & $\begin{array}{r}<20 \\
<20 \\
40 \\
<20 \\
40 \\
\text { NA }\end{array}$ & $\begin{array}{r}<20 \\
<20 \\
40 \\
<20 \\
40 \\
20\end{array}$ & $\begin{array}{r}<20 \\
20 \\
20 \\
<20 \\
40 \\
\text { NA }\end{array}$ \\
\hline
\end{tabular}




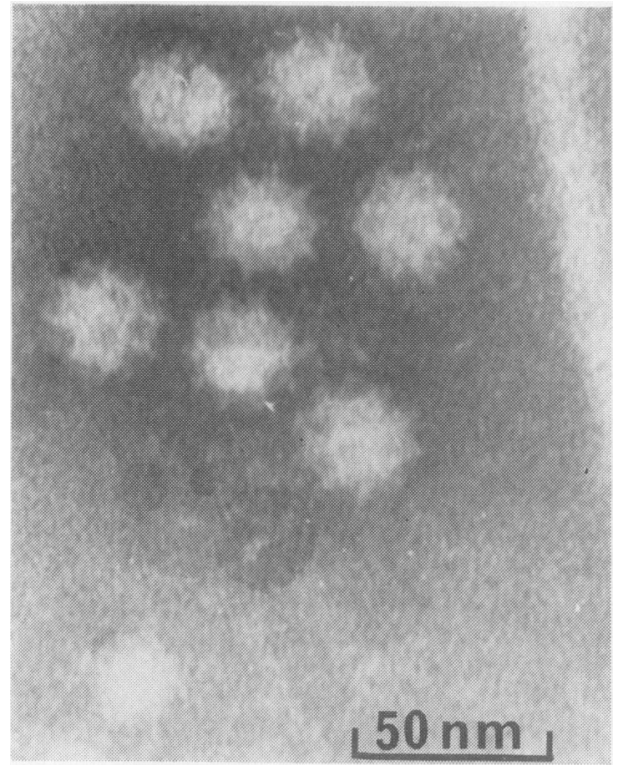

Fig. 2 Calicivirus particles Portsmouth strain $\times 404000$.

the sixth resident from whom only an acute phase serum was available. The serum contained a low titre of specific antibody $1 / 20$ to both the homologous and heterologous strains of calicivirus. The results of cross reactivity tests indicated that these residents only developed an antibody response to the Portsmouth strain antigen. Tests using the Shenley and Piper antigens showed no rises in antibody levels to these strains although two residents, 3 and 5, had low titres of $1 / 40$ against them. This is suggestive of past rather than recent infection with these two strains. These findings indicate that the Portsmouth strain causing this outbreak is serologically distinct from two strains obtained from children.

\section{Discussion}

These findings provide further evidence for the view that there is a calicivirus which is pathogenic in man. All the residents who were investigated virologically showed clear evidence of recent or active infection with calicivirus. Specimens from the other residents and members of staff were discarded before any virological tests had been carried out. There was no evidence of a bacterial cause of infection in any of these individuals and the similarity of their symptoms suggests that they were infected by the same virus.
In this outbreak the duration of symptoms was short, 12 to 36 hours, and virus particles were only detected with difficulty in samples collected within 72 hours of the onset of symptoms. This supports the previous finding ${ }^{3}$ that excretion of virus may closely parallel the duration of symptoms.

The cross reactivity tests indicate that there are at least two distinct serotypes of human calicivirus. This is an interesting finding since other members of the Caliciviridae are known to exist as a number of distinct serotypes. ${ }^{5}$ Further investigations are in progress to determine whether there are other serotypes of "human calicivirus" and to establish if they are related to caliciviruses found in animals.

Research on "human calicivirus" has been hampered by the failure to propagate this virus in cell cultures and by the small amounts of material which can be readily obtained from infants and young children. The finding of caliciviruses in adults should result in larger quantities of antigen and sera becoming available for investigation.

The finding of calicivirus as well as rotavirus causing outbreaks of gastroenteritis ${ }^{6} 7$ in elderly residents in confined communities indicates that a more thorough study of this population is necessary, and again emphasises the need to perform bacteriological and virological investigations in parallel.

\section{References}

${ }^{1}$ Madeley CR, Cosgrove BP. Caliciviruses in man. Lancet 1976;i:199-200.

2 Cubitt WD, McSwiggan DA, Moore W. Winter vomiting disease caused by calicivirus. J Clin Pathol 1979;32:78693.

${ }^{3}$ Cubitt WD, McSwiggan DA, Arstall S. An outbreak of calicivirus infection in a mother and baby unit. $J$ Clin Pathol 1980;33:1095-8.

${ }^{4}$ Chiba S, Sakuma Y, Kogasaka R, et al. An outbreak of gastroenteritis associated with calicivirus in an infant home. J Med Virol 1979;4:249-54.

${ }^{5}$ Schaffer FL. Caliciviruses. In: Fraenkel-Conrat H, Wagner RR, eds. Comprehensive virology: Plenum, 1979: Vol 14, Chapter 14.

${ }^{6}$ Cubitt WD, Holzel H. An outbreak of rotavirus infection in a longstay ward of a geriatric hospital. J Clin Pathol 1980; 33:306-8.

${ }^{7}$ Halvosrud J, Örstavik I. An epidemic of rotavirus associated gastroenteritis in a nursing home for the elderly. Scand J Infect 1980;12:161-4.

Requests for reprints to: WD Cubitt, Department of Microbiology, Public Health Laboratory, Central Middlesex Hospital, Park Royal, London NW10 7NS, England. 